Original Article

\title{
Effects of nitrogen and phosphorus availability on the early growth of two congeneric pairs of savanna and forest species
}

\author{
Efeitos da disponibilidade de nitrogênio e fósforo no crescimento inicial de dois pares \\ congenéricos de espécies de savana e floresta.
}

\author{
B. Paganelia* (D) and M. A. Batalha ${ }^{\mathrm{a}}$ (D) \\ a Federal University of São Carlos, Department of Botany, São Carlos, SP, Brasil
}

\begin{abstract}
In the tropical region, savannas and seasonal forests, both highly diverse biomes, occur side by side, under the same climate. If so, that mosaic cannot be explained solely by climatic variables, but also by fire, water availability and soil status. Nutrient availability in the soil, especially nitrogen and phosphorus, has been postulated to explain the abrupt transitions between savannas and seasonal forests in tropical regions. Plants from these two biomes may present different nutritional strategies to cope with nitrogen and phosphorus limitation. We used two congeneric pairs of trees - each pair with a species from the savanna and another from the neighboring seasonal forest - to test whether savanna and forest species presented different nutritional strategies during their early development. We cultivated 56 individuals from each of these species in a hydroponics system with four treatments: (1) complete Hoagland solution, (2) Hoagland solution without nitrogen, (3) Hoagland solution without phosphorus, and (4) Hoagland solution without nitrogen and phosphorus. After 45 days, we harvested the plants and measured total biomass, root to shoot ratio, height, leaf area, and specific leaf area. Overall, savanna species were lighter, shorter, with smaller leaves, higher specific leaf areas, and higher root to shoot ratios when compared to the forest species. Nitrogen increased the performance of species from both biomes. Phosphorus improved the performance of the forest species and caused toxicity symptoms in the savanna species. Hence, savanna and forest species presented different demands and were partially distinct already as seedlings concerning their nutritional strategies.
\end{abstract}

Keywords: forest, hydroponics, nitrogen, phosphorus, savanna.

\begin{abstract}
Resumo
Em regiões tropicais, savanas e florestas estacionais, biomas altamente diversos, ocorrem lado a lado, sob o mesmo clima. Sendo assim, esse mosaico não pode ser explicado somente por variáveis climáticas, devendo ser considerada a frequência e intensidade de incêndios, disponibilidade de água e status do solo. A disponibilidade de nutrientes no solo, especialmente nitrogênio e fósforo, tem sido postulada para explicar as transições abruptas entre savanas e florestas estacionais nos trópicos. Espécies vegetais desses dois biomas podem apresentar estratégias nutricionais diferentes para lidar com a limitação tanto de nitrogênio como de fósforo. Utilizamos dois pares de árvores congenéricas - cada par com uma espécie típica de savana e outra de floresta estacional vizinha - para testar se as espécies da savana e da floresta apresentaram estratégias nutricionais diferentes durante seu desenvolvimento inicial. Cultivamos 56 indivíduos de cada uma dessas espécies em um sistema hidropônico com quatro tratamentos: (1) solução Hoagland completa, (2) solução Hoagland sem nitrogênio, (3) solução Hoagland sem fósforo e (4) solução Hoagland sem nitrogênio e fósforo. Após 45 dias, colhemos as plantas e medimos a biomassa total, a relação raiz / parte aérea, altura, área foliar e área foliar específica. No geral, as espécies savânicas foram mais leves, menores em altura, área foliar e área foliar específica e apresentaram maiores razões entre biomassa radicular por biomassa aérea quando comparadas às espécies florestais. A oferta de nitrogênio aumentou o desempenho das espécies de ambos biomas. $\mathrm{O}$ fósforo melhorou o desempenho das espécies florestais e causou sintomas de toxicidade nas espécies savânicas. Concluímos que, já como mudas, espécies congenéricas de savana e floresta apresentaram demandas distintas e foram parcialmente diferentes em relação a suas estratégias nutricionais.
\end{abstract}

Palavras-chave: floresta, hidroponia, nitrogênio, fósforo, savanna.

\section{Introduction}

Savannas are characterized by the presence of grasses, sub-shrubs, shrubs, and trees, in varying proportions, and temporal patterns related to seasonality and fire
(Maurin et al., 2014). That biome is typical of the tropical areas, which harbor high biodiversity and some of the most threatened biomes, including the savannas and forests,

*e-mail: paganelibruno@gmail.com

Received: March 25, 2020 - Accepted: October 15, 2020

This is an Open Access article distributed under the terms of the Creative Commons Attribution License, which permits unrestricted use, distribution, and reproduction in any medium, provided the original work is properly cited. 
that often appear in mosaic (Beerling and Osborne, 2006; Kinlock et al., 2017; Myers et al., 2000). The occurrence of savannas and their physiognomic gradient are related not only to climate and fire, but also to herbivory, water availability, carbon dioxide, and soil nutrients (Beerling and Osborne, 2006; Oliveras and Malhi, 2016; Pinheiro and Monteiro, 2010).

Border dynamics between savannas and forests remain poorly understood, despite being intensively studied (Murphy and Bowman, 2012). However, savanna and forest species belong to different functional groups (Silva et al., 2013) and may present different strategies that enable them to respond differently to environmental factors (Barbosa et al., 2014; Miatto et al., 2016). For instance, whereas savanna species tend to be water and nutrient-limited, forest species tend to be limited by light (Dantas et al., 2015). Thus, climate change, soil eutrophication, soil impoverishment, and fire regime may affect the border dynamic between both physiognomies and favor one biome over the other (Hill and Southworth, 2016).

Soils from these two adjoining biomes are very different (Cruz Ruggiero et al., 2002). Savanna soils are usually older and sandy, whereas forest soils are generally younger and clayey (Cruz Ruggiero et al., 2002). Consequently, they present different leaching patterns and nutrient availability, especially concerning nitrogen and phosphorus (Tahir and Marschner, 2017). In savannas, the more intense leaching, the strength of ion adsorption, the frequent fires that volatilize some nutrients, and the older age make the soil more acid, richer in $\mathrm{Al}^{3+}$ and poorer in nitrogen and phosphorus than in forests (Pinheiro and Monteiro, 2010; Vitousek et al., 2010). Since these features can intensely change over short distances, it allows a mosaic in the spatial distribution of these two biomes (Souza and Martins, 2004).

Nitrogen and phosphorus are strong environmental filters, regulating the establishment and prevalence of either savannas or forests, mainly in neighboring areas (Almeida et al., 2018; Pellegrini, 2016). As long as their cycles are being intensively modified, it may pose new challenges to plants (Peng et al., 2019). Their availabilities can also change the savanna and forest functional attributes and trade-offs in biomass allocation differently (Poorter et al., 2012; Zhang et al., 2018). For example, functional traits required for light captures such as height and leaves can be higher in forest species; the trade-off for savanna species, in turn, can be shifted to belowground resources, by high roots investment (Paganeli et al., 2020). Since savanna and forest species evolved under different environmental scenarios, nutritional conditions may impose distinct pressures for the species of these two biomes in their early development (Hoffmann and Franco, 2008; Poorter et al., 2012).

Studies that aim to understand the effects of different nutritional conditions on species strategies may be useful to predict the dynamics of savanna-forest borders in future scenarios (Viani et al., 2011). In this sense, we tested the effects of different nutritional conditions regarding nitrogen and phosphorus availability on two congeneric pairs of savanna and forest species. Thus, we tried to answer the following questions: (1): Do forest plants have more biomass than the savanna plants? (2): Is the root-to-shoot ratio higher in savanna species than the forest ones? (3): Are the forest species taller than the savanna ones? (4): Do the forest species present larger leaves and specific leaves areas than savanna species? (5): Are biomass, height, and leaf area higher when both, savanna and forest seedlings grow on the complete solution?

\section{Materials and Methods}

To account for phylogenetic relatedness (Hoffmann and Franco, 2008), we used two congeneric pairs of species, each pair with one species from the savanna and another from the neighboring seasonal forest. The first pair belonged to the genus Solanum L. (Solanaceae), with S. lycocarpum St. Hil. from the savanna and S. grandiflorum Ruiz and Pav. from the forest; the second pair belonged to the genus Enterolobium Mart. (Fabaceae), with E. gummiferum (Mart.) J. F. Macbr. from the savanna and E. contortisiliquum (Vell.) Morong from the forest. All species are common in central Brazil, in their vegetation types.

We purchased the seeds from nurseries and germinated them in the laboratory. We moistened germitest paper sheets with $10 \mathrm{ml}$ of distilled water (Lessa et al., 2015). We mechanically scarified the Enterolobium seeds and placed 20 of them on Petri dishes with two germitest paper sheets above the seeds and two below. We wrapped the dishes with plastic film and took them to an incubator at $25^{\circ} \mathrm{C}$ and 12-hour photoperiod (Malavasi and Malavasi, 2004). In the Solanum species, we used 12 hours alternating light and dark and high and low temperatures -30 and $20^{\circ} \mathrm{C}$ (Pinto et al., 2007). By using germitest paper sheets as substrate, we reached low germination rates. Thus, adjustments were performed using an alternative inert substrate, which displayed good germination rates, the expanded clay.

We sieved the clay with a $2 \mathrm{~mm}$ soil sieve. Then we sieved the content again with a $1 \mathrm{~mm}$ sieve. Thus, we standardized the grain size between 1 and $2 \mathrm{~mm}$. We washed the substrate repeatedly and abundantly with running water in the first times and with distilled water in the last. We also sterilized it in an ultraviolet chamber for 15 minutes. On each dish, we put $55 \mathrm{~g}$ of clay, 20 seeds on top of this layer, and finally another layer of $55 \mathrm{~g}$ of clay. We moistened each dish with $45 \mathrm{~mL}$ of distilled water. When the radicles were $1 \mathrm{~cm}$ long, we randomly picked 56 seedlings of each species and placed each seedling in a $180 \mathrm{~cm}^{3}$ plastic tube, filled with expanded clay previously described.

During the 2019 summer, we took the plastic tubes to a greenhouse located in São Carlos ( $21^{\circ} 59^{\prime} \mathrm{S}, 47^{\circ} 53^{\prime} \mathrm{W}$; southeastern Brazil), where cooling, humidification, ventilation, and exhaustion were automatically controlled, so that the temperature was kept between $20^{\circ} \mathrm{C}$ and $28^{\circ} \mathrm{C}$, the air relative humidity between $60 \%$ and $80 \%$ under a natural light regime. To test the effect of nitrogen and phosphorous depletion on plant growth, we cultivated the seedlings in closed hydroponic systems, in which the nutrient solutions were recycled (Prado and Casali, 2006; Jensen, 1997). We used four treatments: (1) complete Hoagland solution, (2) Hoagland solution without nitrogen, (3) Hoagland solution without phosphorus, and 
(4) Hoagland solution without nitrogen and phosphorus. All treatments had their ionic strength reduced by $50 \%$ (see Table 1). We measured the initial values and carried out weekly measurements of $\mathrm{pH}$ and conductivity. We added distilled water or solution as necessary whenever the initial values changed. We did a complete exchange of all solutions after 23 days.

For each congeneric pair, we placed eight boxes on aluminum stands. For each treatment, we used two boxes, one for the savanna species and the other for the forest species. To prevent algae proliferation, we covered the boxes with aluminized thermal blankets to avoid light in the solutions. We filled each box with $40 \mathrm{~L}$ of its respective solution. Then, we placed support for 14 plastic tubes. The two boxes of each treatment were connected to a $100 \mathrm{~L}$ reservoir by a silicone hose, at one end with a T-connector, and at the other end with a submersible motor pump that remained inside the reservoir. The solution was propelled by the motor pump, going through the hose, to the T-connector, and the two boxes. We set a timer to propel the solution in five cycles daily: at 06:30, 10:30, $12: 00,14: 30$, and 17:30. The timer remained on for $3 \mathrm{~min}$, the time necessary to move the solutions, homogenize them, and moisten the clay. At the end of each cycle, the solution returned to the reservoir by gravity.

After 45 days, we harvested 14 individuals of each species and each treatment, oven-dried them at $80^{\circ} \mathrm{C}$ for 72 hours, and measured total dry biomass. Biomass is an important functional trait since it is considered the best predictor of community functioning and plant performance (Gignoux et al., 2016; Grime, 1998). We also separated the below from the aboveground portion and weighed their dry masses. Dividing the below by the aboveground part, we obtained the root-to-shoot ratio, which is appropriate to assess biomass allocation (Poorter et al., 2012). Plants adapted in oligotrophic conditions are expected to present higher biomass allocation to roots so that the ratio is a good indicator of resource limitation (Poorter et al., 2012). We measured height by taking the distance from the hypocotyl to the apical bud. We scanned the leaves and measured their areas. We divided the leaf area by dry leaf biomass to calculate the specific leaf area. Height and leaf traits as specific leaf areas play an important role in plant development by improving the light interception, serving as a proxy of its growth performance (Rodriguez and Maiti, 2016).

To answer the five questions posed, we used covariance analyses. In a given model, the response variable was total dry biomass, root to shoot ratio, height, leaf area or specific leaf area; the explanatory variables were biome (savanna or forest), nitrogen (presence or absence), and phosphorus (presence or absence). We also included the interaction terms as explanatory variables (nitrogen + phosphorus, nitrogen + biome, phosphorus + biome, and nitrogen + phosphorus + biome). In the case of the specific leaf area, we also tested whether it was related to height, root-to-shoot ratio, and biome.

\section{Results}

Total biomass was related to the explanatory variables considered together $\left(\mathrm{R}^{2}=0.40 ; \mathrm{P}<0.001\right)$, particularly to nitrogen $(\mathrm{P}<0.001)$, phosphorus $(\mathrm{P}=0.005)$, biome $(\mathrm{P}<0.001)$, the interaction term between nitrogen and biome $(P<0.001)$, and the interaction term between nitrogen and phosphorus $(\mathrm{P}=0.003)$. Individuals of forest species $(1.73 \mathrm{~g} \pm 1.59$, mean $\pm \mathrm{sd}$ ) displayed heavier dry total biomasses $(\mathrm{P}<0.001)$ than individuals of savanna species $(0.66 \mathrm{~g} \pm 0.77)$. Savanna species were heavier in the complete solution $(1.27 \mathrm{~g} \pm 0.80)$ than without phosphorus $(0.67 \mathrm{~g} \pm 0.95)$. Interestingly, the solution lacking both macronutrients had higher total biomass $(0.42 \mathrm{~g} \pm 0.40)$ than that missing nitrogen and phosphorus $(0.42 \mathrm{~g} \pm 0.40)$, and that missing nitrogen $(0.28 \mathrm{~g} \pm 0.34)$. Forest species were heavier in the complete solution $(3.05 \mathrm{~g} \pm 1.91)$ than without phosphorus $(1.99 \mathrm{~g} \pm 1.36)$, nitrogen $(0.98 \mathrm{~g} \pm 1.02)$, and both $(0.90 \mathrm{~g} \pm 0.84)$.

Root to shoot ratio was related to the explanatory variables considered together $\left(\mathrm{R}^{2}=0.47 ; \mathrm{P}<0.001\right)$, higher $(\mathrm{P}<0.001)$ in savanna $(0.68 \pm 0.30)$ than in forest species $(0.38 \pm 0.12)$. Both nitrogen $(P<0.001)$ and phosphorus $(\mathrm{P}<0.001)$ affected this trait significantly. Savanna species presented higher ratio in the solution without both nutrients $(0.90 \pm 0.16)$, than in the complete solution $(0.48 \pm 0.17)$, without nitrogen only $(0.40 \pm 0.73)$, and without phosphorus only $(0.25 \pm 0.59)$. Forest species presented higher ratio in the solution without phosphorus only $(0.42 \pm 0.09)$, then without both nutrients $(0.39 \pm 0.12)$, without nitrogen only $(0.38 \pm 0.13)$, and in the complete

Table 1. Treatments $(\mathrm{Com}=$ complete Hoagland solution; $-\mathrm{N}=$ Hoagland solution without nitrogen; $-\mathrm{P}=$ Hoagland solution without phosphorus; - $\mathrm{NP}=$ Hoagland solution without nitrogen and phosphorus) used for plant growth, with their respective concentrations. In the cells, there are the volumes $(\mathrm{ml})$ of different $1 \mathrm{M}$ stock solutions previously prepared and added to $90 \mathrm{~L}$ of distilled water.

\begin{tabular}{ccccccccc}
\hline & \multicolumn{7}{c}{ Nutrients } \\
\cline { 2 - 7 } Treatments & $\mathbf{K H}_{2} \mathbf{P O}_{4}$ & $\mathbf{K N O}_{3}$ & $\mathbf{C a}\left(\mathbf{N O}_{3}\right)_{2}$ & $\mathbf{M g S O}_{4}$ & $\mathbf{K C l}$ & $\mathbf{C a C l}_{2}$ & Micronutrients & $\begin{array}{c}\text { Ferric and } \\
\text { monosodium EDTA }\end{array}$ \\
\hline Com & 90 & 90 & 135 & 90 & 0 & 0 & 45 & 45 \\
$-\mathrm{N}$ & 90 & 0 & 0 & 90 & 90 & 135 & 45 & 45 \\
$-\mathrm{P}$ & 0 & 90 & 135 & 90 & 90 & 0 & 45 & 45 \\
-NP & 0 & 0 & 0 & 90 & 180 & 135 & 45 & 45 \\
\hline
\end{tabular}


solution $(0.30 \pm 0.09)$. The interaction term between nitrogen and biome was also significant $(\mathrm{P}<0.001)$ (see Figure 1).

Individuals of the forest $(23.14 \mathrm{~cm} \pm 18.6)$ were taller $\left(\mathrm{R}^{2}=0.28 ; \mathrm{P}<0.001\right)$ than those of the savanna $(11.25 \mathrm{~cm} \pm 6.4)$. Height was related to nitrogen $(P<0.001)$, but not to phosphorus $(\mathrm{P}=0.154)$. The effect of nitrogen on height depended on the biome $(\mathrm{P}=0.001)$. Individuals of the savanna species grew taller in the complete solution (14.48 \pm 6.15 ), then without phosphorus only (11.12 \pm 6.04$)$, without nitrogen $(9.92 \pm 6.68)$, and without both nutrients $(9.5 \pm 5.81)$. Individuals of the forest species grew taller in the complete solution $(33.53 \pm 21.71)$, then without phosphorus only (27.05 \pm 20.16$)$, without both nutrients $(16.15 \pm 12.49)$, and nitrogen only (15.82 \pm 12.98$)$ (see Figure 2).

Leaves were larger $\left(\mathrm{R}^{2}=0.75 ; \mathrm{P}<0.001\right)$ in forest $\left(201.40 \mathrm{~cm}^{2}\right.$ $\pm 157.16)$ than in savanna species $\left(72.90 \mathrm{~cm}^{2} \pm 58.23\right)$. All explanatory variables were significant $(\mathrm{P}<0.01$ in all cases). Savanna species presented larger leaves in the complete solution (142.34 \pm 29.15 ), then without phosphorus only (67.09 \pm 54.75$)$, without nitrogen (43.95 \pm 42.35$)$, and without both nutrients ( $37.74 \pm 32.25)$. Forest species presented larger leaves in the complete solution (399.91 $\pm 95.99)$, then without phosphorus only $(225.30 \pm 107.14)$, without nitrogen only (90.92 \pm 91.09$)$, and both nutrients $(89.45 \pm 73.75)$.

Specific leaf area was not related to the explanatory variables taken all together $\left(R^{2}=0.05 ; P=0.113\right)$, but it was marginally different between the biomes $(P=0.055)$, higher in savanna $(552.06 \mathrm{~cm} 2 \mathrm{~g}-1 \pm 1050.62)$ than in forest species ( $360.32 \mathrm{~cm} 2 \mathrm{~g}-1 \pm 198.16$ ). The interaction terms between nitrogen and phosphorus $(\mathrm{P}=0.069)$ and among nitrogen, phosphorus, and biome $(\mathrm{P}=0.046)$ were,

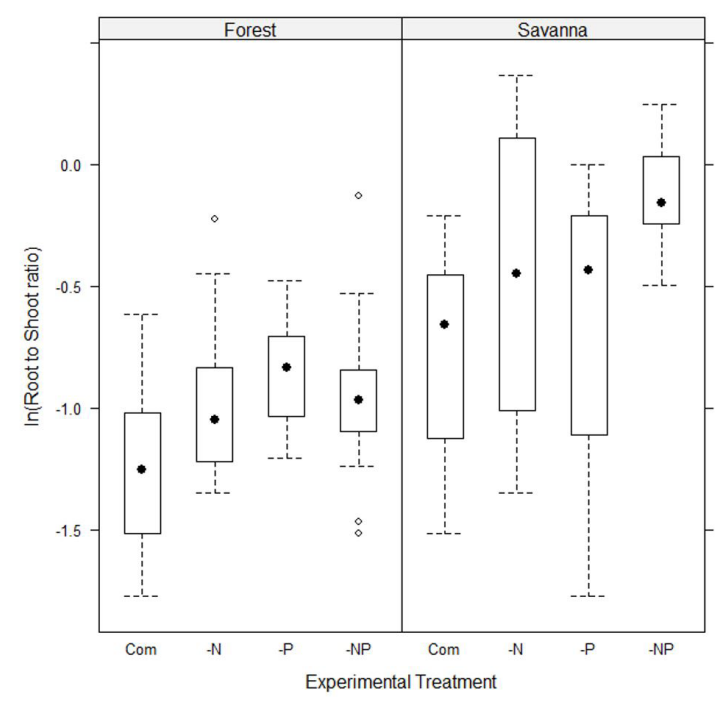

Figure 1. On that figure are the logarithms of root-to-shoot ratio square root in two pairs of congeneric species. The forest houses data from two species (E. contortisiliquum and S. grandiflorum), as do the savanna (E. gummiferum and S. lycocarpum). The complete solution is represented by Com; The solution without N by -N; The solution without P by -P; The solution without both nutrients by -NP. respectively, marginally significant and significant. Savanna species presented higher specific leaf areas in the solution without nitrogen (791.12 $\left.\mathrm{cm}^{2} \mathrm{~g}^{-1} \pm 1560.89\right)$, then in the solution without phosphorus (695.36 $\left.\mathrm{cm}^{2} \mathrm{~g}^{-1} \pm 1285.85\right)$, in the complete solution ( $\left.416.03 \mathrm{~cm}^{2} \mathrm{~g}^{-1} \pm 505.46\right)$, in the solution without both nutrients $\left(300.60 \mathrm{~cm}^{2} \mathrm{~g}^{-1} \pm 179.51\right)$. Forest species presented higher specific leaf areas in the solution without nitrogen (393.6 $\left.\mathrm{cm}^{2} \mathrm{~g}^{-1} \pm 245.36\right)$, then in the complete solution (372.50 $\left.\mathrm{cm}^{2} \mathrm{~g}^{-1} \pm 202.14\right)$, in the solution without both nutrients $\left(358.88 \mathrm{~cm}^{2} \mathrm{~g}^{-1}\right.$ $\pm 217.64)$, and the solution without phosphorus (302.30 $\mathrm{cm}^{2} \mathrm{~g}^{-1} \pm 108.29$ ). Specific leaf area was related to height, root to shoot ratio, and biome $\left(R^{2}=0.35 ; P<0.001\right)$.

\section{Discussion}

Concerning their growth under different nitrogen and phosphorus supply, congeneric savanna and forest species displayed distinct functional traits and patterns of biomass increment and allocation from the very early stages of their life cycles, as predicted, for example, by Poorter et al. (2012) and Zhang et al., (2018). Although species from these biomes live under different nutrient availability (Cruz Ruggiero et al., 2002), both congeneric pairs that we analyzed were limited by nitrogen. Overall, when they were supplied with that element, they grew faster and higher. Phosphorus, on its turn, increased the performance, but in general, the growth improvement was less pronounced than those provided by the nitrogen.

Such pattern was evident, for instance, in total biomass, with species from the two biomes showing different responses to nutrient addition. Biomass increment provided by nitrogen was enhanced by phosphorus in species from both biomes. However, in the savanna species, when there was no nitrogen, the addition of phosphorus reduced the biomass acquisition - perhaps an indication of phosphorus toxicity (Mohidin et al., 2015; Paganeli et al., 2020; Silber et al., 2002). (see Figure 2). As phosphorus availability in savannas tends to be low, species from this biome may present strategies to cope with such hindrances, as low demand and growth rates (Matzek and Vitousek, 2009; Pellegrini 2016). Since the seedlings in general usually present a high mortality rate (Collet and Le Moguedec, 2007), if it decreases the external phosphorus consume in the early stages of life, this strategy reduces the phosphorus competition at the community level, even if momentary (Paganeli et al., 2020). On the other hand, the forest species displayed high nutritional demand, shown by intense biomass reduction when growing in solutions with nitrogen or phosphorus absence.

These growth patterns could be fit into different plant nutritional strategies, the conservative (adopted by less demanding species) and the acquisitive ones (typical for fast-growing species), which allow savanna and forest species to live in contrasting habitats in neighboring sites (Caplan et al., 2017; Chacón-Madrigal et al., 2018; Maracahipes et al., 2018). Both strategies are consistent with our results and the evolutionary history of savanna and forest species. It makes possible the prevalence of one vegetation type over the other concerning competition 


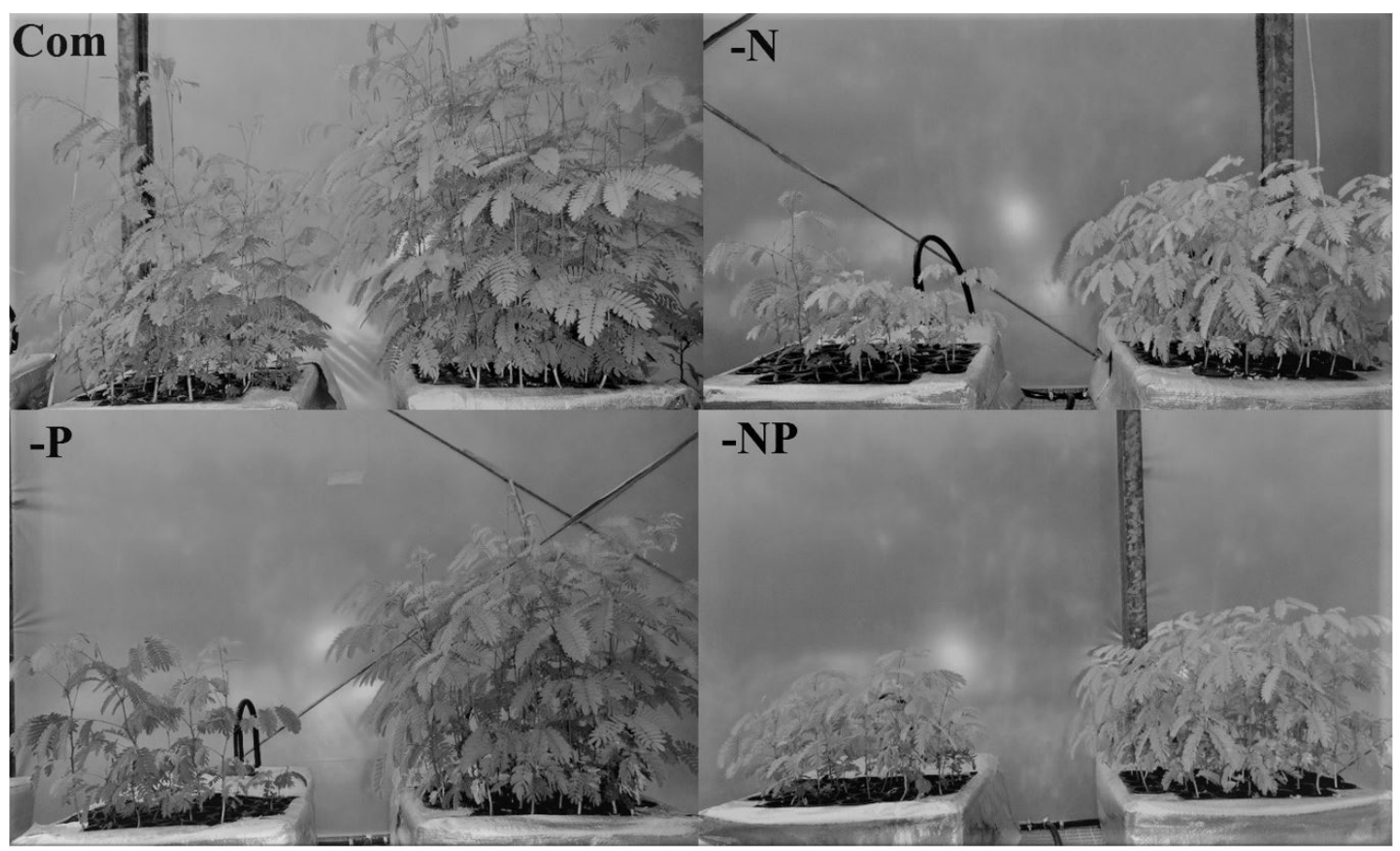

Figure 2. The effect of our four treatments (Com: Complete Hoagland solution; -N: Solution without nitrogen; -P: Solution without phosphorus and -NP: Solution without both macronutrients) in the grow of a congeneric pair of species after 45 days of experiment. The boxes in the left side represent the savanna species (Enterolobium gummiferum), those on the right side, the forest ones (E. contortisiliquum).

under the current and the future nutrients unbalanced inputs, changing the functional diversity on those mosaics (Paganeli et al., 2020; Peng et al., 2019; Wallis and Bobbink, 2017).

Admittedly, environmental quality and community functioning are complex and cannot be defined solely by total biomass (Norberg, 2004). Regarding plant biomass, the root to shoot ratio can be interpreted as where below or aboveground - the incorporated organic matter was preferentially allocated, allowing species to be more adapted to forage with the roots or the aerial organs (Tuller et al., 2018). It also implies differences in vegetation structure (Potter and Klooster, 1997) and, consequently, provides information about ecological interaction below or aboveground (Schuldt et al., 2017).

Since the savanna species evolved in poorer soils, this process could be visualized by the strategy of higher root to shoot ratio in savanna species when compared to forest ones (Miatto et al., 2016; Qi et al., 2019). The savannas species displayed a huge ability to forage for nutrients, and more intensive capacity related to nitrogen. When those species grew in solution without this element, the root biomass allocation almost doubled, and the forest species showed a weak mechanism to nutrient foraging since its trait does not change according to treatments as the savanna species did. It exemplifies different evolutionary processes in these two neighboring biomes, which could have culminated in niche differentiation and speciation, diminishing competition, and favoring their coexistence (Rueffler et al., 2006).
The different patterns of biomass allocation in forest species can be viewed indirectly by their bigger leaves and tallest individuals compared with congeneric savanna species (Hoffmann and Franco, 2003; Hoffmann et al., 2005; Hoffmann and Franco, 2008). It also can be interpreted as an evolutionary response, since natural selection on forest species may have acted in favor of distinct and opposite resource than savannas (Maracahipes et al., 2018), the light, and thus, in the aerial growth (Dantas et al., 2015; Gignoux et al., 2016; Rodriguez and Maiti, 2016). However, plant height showed a huge nitrogen dependency to achieve the potential growth, especially in forest species, which displayed massive differences when grew in solutions with and without this nutrient, for example. In all treatments with nitrogen absence, the forest species reduced more than $20 \%$ of its height compared with savannas species under the same nutritional conditions. The height is recognized as the most important functional trait to compete for light (Gignoux et al., 2016; Moles et al., 2009) and was strongly decreased by nutritional deficiency.

Although the height able the plants to intercept the light, the photosynthetically active organ is the leaf. The capacity of leaves to intercept the light could be changed in many ways, including increasing its area (Duursma et al., 2012). However, the light does not need just to be intercepted, it needs to be used, and in environments with adequate nutritional supply, the protein concentrations, nucleic acids, and energy molecules can increase and enhance the plant's metabolism (Niinemets, 2010). These molecules have nitrogen and phosphorus in their constitution, and although the plants may still have been under cotyledons 
contents influence (Milberg and Lamont, 1997; Green and Juniper, 2004), the external nutritional offers were very relevant in diversifying the plants' leaf areas. Similar to previous traits, nitrogen was also the most important nutrient to increase the leaf area, but the largest leaves in solution with all nutrients, in both biomes, showed a high nutrients dependency to improve efficient light use, including in savannas seedlings.

The efficient light use can be predicted by specific leaf areas, which is usually higher in forest species than in the savannas (Hoffmann and Franco, 2003; Hoffmann et al., 2005; Hoffmann and Franco, 2008). However, we did not find it since the savanna species presented higher specific leaf areas. This difference may have come from our methods, since the greatest physiological problem for plants with large leaf areas is the high-water loss due to transpiration (Taiz et al., 2015), what did not happen in our experiment since we used hydroponics technique. According to Oliveras and Malhi (2016), the savannas and forest congeneric species also present different strategies to deal with water availability gradients. Thus, using hydroponic techniques may have led to our clashing results compared to previous work.

There was one more different strategy adopted by species from these vegetation types. Whereas savanna species displayed the smallest specific leaf area in the treatment with shorter individuals, they also had higher biomass allocation to roots, showing that they were able to keep their morphological characteristics that provide better competition capacity to aboveground resources, even in a life phase in which light incidence is scarce (Hoffmann and Franco, 2008). That trade-off was different on forest species since the same treatment that they presented the shorter individuals also presented the highest specific leaf areas. It seems to be very useful since if the nutritional resources cannot support the growth in height and leave areas, the investment in specific leaf areas on these scenarios can be the best nutritional strategy to enhance their ability to compete for light. When specific leaf area is higher, water loss by transpiration increases (Liu et al., 2017), but it is not a problem in forest environments, where water availability is also higher (Ellison et al., 2017). Thus, when the forest species present less efficient functional attributes in light capture, they still try to display another mechanism that optimizes not only plant growth but also efficiency in light capture (Prado Junior et al., 2015; Liu et al., 2017), highlighting their adaptative strategies to survive in closed environments.

The functional traits difference displayed between savanna and forest species was strongly influenced by the nutritional conditions suggesting different strategies on typical species from those biomes. It highlights the different pressures experienced by these different functional groups throughout their evolutionary history (Hoffmann and Franco, 2008; Silva et al., 2013). Our results pointed out that nitrogen was the most important nutrient, shaping the functional traits in seedlings from both savanna and forest species. As nutrient availability - especially nitrogen - is changing, one biome may be favored over the other, altering the structure and functioning of the savanna and forest mosaic (Hill and Southworth, 2016). Forest encroachment in savannas landscapes is a global phenomenon already described by changes in the fire regime (Staver et al., 2011; Stevens et al., 2017). It may also be related to changes in nitrogen and phosphorus availability.

\section{Acknowledgements}

We are grateful for the financial support provided by the São Paulo Research Foundation (FAPESP), grants 2017/04937-8 and 2018/11557-0. The second author is grateful to the National Council for Scientific and Technological Development (CNPq) for the productivity grant 305912/2013-5. We emphasize that there are no conflicts of interest to disclose.

\section{References}

ALMEIDA, H.A., BAHIA, T.O., GÉLVEZ-ZÚÑIGA, I. and FERNANDES, G.W., 2018. Together yet separate: variation in soil chemistry determines differences in the arboreal-shrub structure of two contiguous rupestrian environments. Acta Botanica Brasílica, vol. 32, no. 4, pp. 578-587. http://dx.doi.org/10.1590/0102$33062018 \mathrm{abb} 0013$.

BARBOSA, E.R., VAN LANGEVELDE, F., TOMLINSON, K.W., CARVALHEIRO, L.G., KIRKMAN, K., DE BIE, S., 2014. Tree species from different functional groups respond differently to environmental changes during establishment. Oecologia, vol. 174, no. 4, pp. 1345-1357. http://dx.doi.org/10.1007/s00442013-2853-y. PMid:24337711.

BEERLING, D.J. and OSBORNE, C.P., 2006. The origin of the savanna biome. Global Change Biology, vol. 12, no. 11, pp. 2023-2031. http://dx.doi.org/10.1111/j.1365-2486.2006.01239.x.

CAPLAN, J.S., STONE, B.W.G., FAILLACE, C.A., LAFOND, J.J., BAUMGARTEN, J.M., MOZDZER, T.J., DIGHTON, J., MEINERS, S.J., GRABOSKY, J.C. and EHRENFELD, J.G., 2017. Nutrient foraging strategies are associated with productivity and population growth in forest shrubs. Annals of Botany, vol. 119, no. 6, pp. 977-988. http://dx.doi.org/10.1093/aob/mcw271.https://www. ncbi.nlm.nih.gov/entrez/query.fcgi? $\mathrm{cmd}=$ Retrieve\&db=PubMe d\&list_uids=28119293\&dopt=Abstract

CHACÓN-MADRIGAL, E., WANEK, W., HIETZ, P. and DULLINGER, $S, 2018$. Traits indicating a conservative resource strategy are weakly related to narrow range size in a group of neotropical trees. Perspectives in Plant Ecology, Evolution and Systematics, vol. 32, pp. 30-37. http://dx.doi.org/10.1016/j.ppees.2018.01.003.

COLLET, C. and LE MOGUEDEC, G., 2007. Individual seedling mortality as a function of size, growth and competition in naturally regenerated beech seedlings. Forestry. International Journal of Forestry Research, vol. 80, pp. 359-370. http://dx.doi. org/10.1093/forestry/cpm016.

CRUZ RUGGIERO, P.G., BATALHA, M.A., PIVELLO, V.R. and MEIRELLES, S.T., 2002. Soil-vegetation relationships in cerrado (Brazilian savanna) and semideciduous forest, southeastern Brazil. Plant Ecology, vol. 160, no. 1, pp. 1-16. http://dx.doi. org/10.1023/A:1015819219386.

DANTAS, V.L., BATALHA, M.A., FRANÇA, H. and PAUSAS, J.G., 2015. Resource availability shapes fire-filtered savannas. Journal of Vegetation Science, vol. 26, no. 2, pp. 395-403. http://dx.doi. org/10.1111/jvs.12247. 
DUURSMA, R.A., FALSTER, D.S., VALLADARES, F., STERCK, F.J., PEARCY, R.W., LUSK, C.H., SENDALL, K.M., NORDENSTAHL, M., HOUTER, N.C., ATWELL, B.J., KELLY, N., KELLY, J.W.G., LIBERLOO, M., TISSUE, D.T., MEDLYN, B.E. and ELLSWORTH, D.S., 2012. Light interception efficiency explained by two simple variables: a test using a diversity of small- to medium-sized woody plants. The New Phytologist, vol. 193, no. 2, pp. 397-408. http://dx.doi. org/10.1111/j.1469-8137.2011.03943.x. PMid:22066945.

ELLISON, D., MORRIS, C.E., LOCATELLI, B., SHEIL, D., COHEN, J., MURDIYARSO, D., GUTIERREZ, V., NOORDWIJK, M., CREED, I.F., POKORNY, J., GAVEAU, D., SPRACKLEN, D.V., TOBELLA, A.B., ILSTEDT, U., TEULING, A.J., GEBREHIWOT, S.G., SANDS, D.C., MUYS, B., VERBIST, B., SPRINGGAY, E., SUGANDI, Y. and SULLIVAN, C.A., 2017. Trees, forests and water: cool insights for a hot world. Global Environmental Change, vol. 43, pp. 51-61. http://dx.doi.org/10.1016/j.gloenvcha.2017.01.002.

GIGNOUX, J., KONATÉ, S., LAHOREAU, G., LE ROUX, X. and SIMIONI, G., 2016. Allocation strategies of savanna and forest tree seedlings in response to fire and shading: outcomes of a field experiment. Scientific Reports, vol. 6, no. 1, pp. 1-15. http:// dx.doi.org/10.1038/srep38838. PMid:28000732.

GREEN, P.T. and JUNIPER, P.A., 2004. Seed-seedling allometry in tropical rainforest trees: seed mass-related patterns of resource allocation and the 'reserve effect'. Journal of Ecology, vol. 92, no. 3, pp. 397-408. http://dx.doi.org/10.1111/j.00220477.2004.00889.x.

GRIME, J.P., 1998. Benefits of plant diversity to ecosystems: immediate, filter and founder effects. Journal of Ecology, vol. 86, no. 6, pp. 902-910. http://dx.doi.org/10.1046/j.13652745.1998.00306.x.

HILL, M.J. and SOUTHWORTH, J., 2016. Anthropogenic change in savannas and associated forest biomes. Journal of Land Use Science, vol. 11, no. 1, pp. 1-6. http://dx.doi.org/10.1080/1747 423X.2016.1145949.

HOFFMANN, W.A. and FRANCO, A.C., 2003. Comparative growth analysis of tropical forest and savanna woody plants using phylogenetically independent contrasts. Journal of Ecology, vol. 91, no. 3, pp. 475-484. http://dx.doi.org/10.1046/j.13652745.2003.00777.x.

HOFFMANN, W.A. and FRANCO, A.C., 2008. The importance of evolutionary history in studies of plant physiological ecology: examples from cerrados and forest of central Brazil. Brazilian Journal of Plant Physiology, vol. 20, no. 3, pp. 247-256. http:// dx.doi.org/10.1590/S1677-04202008000300008.

HOFFMANN, W.A., FRANCO, A.C., MOREIRA, M.Z. and HARIDASAN, M., 2005. Specific leaf area explains differences in leaf traits between congeneric savanna and forest trees. Functional Ecology, vol. 19, no. 6, pp. 932-934. http://dx.doi.org/10.1111/j.13652435.2005.01045.x.

JENSEN, M.H., 1997. Hydroponics. HortScience, vol. 32, no. 6, pp. 1018-1021. http://dx.doi.org/10.21273/HORTSCI.32.6.1018.

KINLOCK, N.L.L., PROWANT, E.M., HERSTOFF, E.M., FOLEY, C.M., AKIN-FAJIYE, M., BENDER, N., UMARANI, M., RYU, H.Y., SSEN, B. and GUREVITCH, J., 2017. Explaining global variation in the latitudinal diversity gradient: meta-analysis confirms known patterns and uncovers new ones. Global Ecology and Biogeography, vol. 27, no. 1, pp. 125-141. http://dx.doi. org/10.1111/geb.12665.

LESSA, B.F.T., ALMEIDA, J.P.N., et al 2015. Germinación y crecimiento de plántulas de Enterolobium contortisiliquum en función del peso de lasemilla y las condiciones de temperatura y luz. Agrociência, vol. 49, pp. 315-327.
LIU, M., WANG, Z., LI, S., LÜ, X., WANG, X. and HAN, X., 2017. Changes in specific leaf area of dominant plants in temperate grasslands along a $2500-\mathrm{km}$ transect in northern China. Scientific Reports, vol. 7, no. 1, pp. 10780. http://dx.doi.org/10.1038/s41598-01711133-z. PMid:28883421.

MALAVASI, U.C. and MALAVASI, M.M., 2004. Dormancy breaking and germination of Enterolobium contortisiliquum (Vell.) morong seed. Brazilian Archives of Biology and Technology, vol. 47, no. 6, pp. 851-854. http://dx.doi.org/10.1590/S151689132004000600003.

MARACAHIPES, L., CARLUCCI, M.B., LENZA, E., MARIMON, B.S., MARIMON JUNIOR, B.H., GUIMARÃES, F.A.G. and CIANCIARUSO, M.V., 2018. How to live in contrasting habitats? Acquisitive and conservative strategies emerge at inter- and intraspecific levels in savanna and forest woody plants. Perspectives in Plant Ecology, Evolution and Systematics, vol. 34, pp. 17-25. http:// dx.doi.org/10.1016/j.ppees.2018.07.006.

MATZEK, V. and VITOUSEK, P.M., 2009. N:P stoichiometry and protein: RNA ratios in vascular plants: an evaluation of the growth-rate hypothesis. Ecology Letters, vol. 12, no. 8, pp. 765-771. http://dx.doi.org/10.1111/j.1461-0248.2009.01310.x. PMid: 19392715.

MAURIN, O., DAVIES, T.J., BURROWS, J.E., DARU, B.H., YESSOUFOU, K., MUASYA, A.M., VAN DER BANK, M. and BOND, W.J., 2014. Savanna fire and the origins of the "underground forest" of Africa. The New Phytologist, vol. 204, no. 1, pp. 201-214. http:// dx.doi.org/10.1111/nph.12936. PMid:25039765.

MIATTO, R.C., WRIGHT, I.J. and BATALHA, M.A., 2016. Relationships between soil nutrient status and nutrient-related leaf traits in Brazilian cerrado and seasonal forest communities. Plant and Soil, vol. 404, no. 1-2, pp. 12-33. http://dx.doi.org/10.1007/ s11104-016-2796-2.

MILBERG, P. and LAMONT, B.B., 1997. Seed/cotyledon size and nutrient content play a major role in early performance of species on nutrient-poor soil. The New Phytologist, vol. 137, no. 4, pp. 665-672. http://dx.doi.org/10.1046/j.1469-8137.1997.00870.x.

MOHIDIN, H., HANAFI, M.M., RAFII, M.Y., ABDULLAH, S.N.A., IDRIS, A.S., MAN, S., IDRIS, J. and SAHEBI, M., 2015. Determination of optimum levels of nitrogen, phosphorus and potassium of oil palm seedlings in solution culture. Bragantia, vol. 74, no. 3, pp. 247-254. http://dx.doi.org/10.1590/1678-4499.0408.

MOLES, A.T., WARTON, D.I., WARMAN, L., SWENSON, N.G., LAFFAN, S.W., ZANNE, A.E., PITMAN, A., HEMMINGS, F.A. and LEISHMAN, M.R., 2009. Global patterns in plant height. Journal of Ecology, vol. 97, no. 5, pp. 923-932. http://dx.doi.org/10.1111/j.13652745.2009.01526.x.

MURPHY, B.P. and BOWMAN, D.M.J.S., 2012. What controls the distribution of tropical forest and savanna? Ecology Letters, vol. 15, no. 7, pp. 748-758. http://dx.doi.org/10.1111/j.14610248.2012.01771.x. PMid:22452780.

MYERS, N., MITTERMEIER, R.A., MITTERMEIER, C.G., DA FONSECA, G.A. and KENT, J., 2000. Biodiversity hotspots for conservation priorities. Nature, vol. 403, no. 6772, pp. 853-858. http://dx.doi. org/10.1038/35002501. PMid:10706275.

NIINEMETS, Ü., 2010. A review of light interception in plant stands from leaf to canopy in different plant functional types and in species with varying shade tolerance. Ecological Research, vol. 25, no. 4, pp. 693-714. http://dx.doi.org/10.1007/s11284-010-0712-4.

NORBERG, J., 2004. Biodiversity and ecosystem functioning: a complex adaptive systems approach. American Society of Limnology and Oceanography, vol. 49, no. 4part2, pp. 1269-1277. http://dx.doi.org/10.4319/lo.2004.49.4_part_2.1269. 
OLIVERAS, I. and MALHI, Y., 2016. 2016. Many shades of green: The dynamic tropical forest-savannah transition zones. Philosophical Transactions of the Royal Society of London. Series B. Biological Science, vol. 371, no. 1703, pp. 20150308. http://dx.doi.org/10.1098/rstb.2015.0308. PMid:27502373.

PAGANELI, B., DEXTER, K.G. and BATALHA, M.A., 2020. Early growth in a congeneric pair of savanna and seasonal forest trees under different nitrogen and phosphorus availability. Theoretical and Experimental Plant Physiology, vol. 32, no. 1, pp. 1-12. http:// dx.doi.org/10.1007/s40626-019-00164-8.

PELLEGRINI, A.F.A., 2016. Nutrient limitation in tropical savannas across multiple scales and mechanisms. Ecology, vol. 97, no. 2, pp. 313-324. http://dx.doi.org/10.1890/15-0869.1. PMid:27145607.

PENG, Y., PENG, Z., ZENG, X. and HOUX, J.H. 3rd., 2019. Effects of nitrogen-phosphorus imbalance on plant biomass production: a global perspective. Plant and Soil, vol. 436, no. 1-2, pp. 245-252. http://dx.doi.org/10.1007/s11104-018-03927-5.

PINHEIRO, M. and MONTEIRO, R., 2010. Contribution to the discussions on the origin of the cerrado biome: brazilian savanna. Brazilian Journal of Biology $=$ Revista Brasileira de Biologia, vol. 70, no. 1, pp. 95-102. http://dx.doi.org/10.1590/ S1519-69842010000100013. PMid:20231964.

PINTO, L.V., DA SILVA, E.A., DAVIDE, A.C., DE JESUS, V.A., TOOROP, P.E. and HILHORST, H.W., 2007. Mechanism and control of Solanum lycocarpum seed germination. Annals of Botany, vol. 100, no. 6, pp. 1175-1187. http://dx.doi.org/10.1093/aob/ mcm211. PMid:17855380.

POORTER, H., NIKLAS, K.J., REICH, P.B., OLEKSYN, J., POOT, P. and MOMMER, L., 2012. Biomass allocation to leaves, stems and roots: meta-analysis of interspecific variation and environmental control. The New Phytologist, vol. 193, no. 1, pp. 30-50. http:// dx.doi.org/10.1111/j.1469-8137.2011.03952.x. PMid:22085245.

POTTER, C.S. and KLOOSTER, S.A., 1997. Global model estimates of carbon and nitrogen storage in litter and soil pools: response to changes in vegetation quality and biomass allocation, Tellus B. Chemical and Physical Meteorology., vol. 49, no. 1, pp. 1-17. http://dx.doi.org/10.3402/tellusb.v49i1.15947.

PRADO JÚNIOR, J., SCHIAVINI, I., VALE, V., LOPES, S., ARANTES, C. and OLIVEIRA, A.P., 2015. Functional leaf traits of understory species: strategies to different disturbance severities. Brazilian Journal of Biology $=$ Revista Brasileira de Biologia, vol. 75, no. 2, pp. 339-346. http://dx.doi.org/10.1590/1519-6984.12413. PMid:26132016.

PRADO, C.H.B.A. and CASALI, C. 2006. Fisiologia Vegetal: práticas em relações hídricas, fotossíntese e nutrição mineral. 450 p. São Carlos: Manole.

QI, Y., WEI, W., CHEN, C. and CHEN, L., 2019. Plant root-shoot biomass allocation over diverse biomes: A global synthesis. Global Ecology and Conservation, vol. 18, pp. e00606. http:// dx.doi.org/10.1016/j.gecco.2019.e00606.

RODRIGUEZ, H.G. and MAITI, R., 2016. Biodiversity of leaf traits in woody plant species in northeastern Mexico: a synthesis. Forest Research, vol. 5, pp. 169. http://dx.doi.org/10.4172/21689776.1000169.

RUEFFLER, C., VAN DOOREN, T.J., LEIMAR, O. and ABRAMS, P.A., 2006. Disruptive selection and then what? Trends in Ecology \& Evolution, vol. 21, no. 5, pp. 238-245. http://dx.doi. org/10.1016/j.tree.2006.03.003. PMid:16697909.
SCHULDT, A., BRUELHEIDE, H., BUSCOT, F., ASSMANN, T., ERFMEIER, A., KLEIN, A.M., MA, K., SCHOLTEN, T., STAAB, M., WIRTH, C., ZHANG, J. and WUBET, T., 2017. Belowground top-down and aboveground bottom-up effects structure multitrophic community relationships in a biodiverse forest. Scientific Reports, vol. 7, no. 1, pp. 4222. http://dx.doi.org/10.1038/s41598-01704619-3. PMid:28652616.

SILBER, A., BEN-JAACOV, J., ACKERMAN, A., BAR-TAL, A., LEVKOVITCH, I., MATSEVITZ-YOSEF, T., SWARTZBERG, D., RIOV, J. and GRANOT, D., 2002. Interrelationship between phosphorus toxicity and sugar metabolism in Verticordia plumosa L. Plant and Soil, vol. 245, no. 2, pp. 249-260. http://dx.doi.org/10.1023/A:1020432512980.

SILVA, L.C.R., HOFFMANN, W.A., ROSSATTO, D.R., HARIDASAN, M., FRANCO, A.C. and HORWATH, W.R., 2013. Can savannas become forests? A coupled analysis of nutrient stocks and fire thresholds in central Brazil. Plant and Soil, vol. 373, no. 1-2, pp. 829-842. http://dx.doi.org/10.1007/s11104-013-1822-x.

SOUZA, A.F. and MARTINS, F.R., 2004. Microsite specialization and spatial distribution of Geonoma brevispata, a clonal palm in south-eastern Brazil. Ecological Research, vol. 19, no. 5, pp. 521-532. http://dx.doi.org/10.1111/j.1440-1703.2004.00670.x.

STAVER, A.C., ARCHIBALD, S. and LEVIN, S.A., 2011. The global extent and determinants of savanna and forest as alternative biome states. Science, vol. 334, no. 6053, pp. 230-232. http://dx.doi. org/10.1126/science.1210465. PMid:21998389.

STEVENS, N., LEHMANN, C.E., MURPHY, B.P. and DURIGAN, G., 2017. Savanna woody encroachment is widespread across three continents. Global Change Biology, vol. 23, no. 1, pp. 235-244. http://dx.doi.org/10.1111/gcb.13409. PMid:27371937.

TAHIR, S. and MARSCHNER, P., 2017. Clay addition to sandy soil reduces nutrient leaching: effect of clay concentration and ped size. Communications in Soil Science and Plant Analysis, vol. 48, no. 15, pp. 1813-1821. http://dx.doi.org/10.1080/00103624.2017.1395454.

TAIZ, L., ZEIGER, E., MøLLER, I.M., and MURPHY, A. 2015. Plant physiology and development. 6th ed. Sunderland, CT: Sinauer Associates. $761 \mathrm{p}$.

TULLER, J., MARQUIS, R.J., ANDRADE, S.M.M., MONTEIRO, A.B. and FARIA, L.D.B., 2018. Trade-offs between growth, reproduction and defense in response to resource availability manipulations. PLoS One, vol. 13, no. 8, pp. 1-12. http://dx.doi.org/10.1371/ journal.pone.0201873. PMid:30133458.

VIANI, R.A.G., RODRIGUES, R.R., DAWSON, T.E. and OLIVEIRA, R.S., 2011. Savanna soil fertility limits growth but not survival of tropical forest tree seedlings. Plant and Soil, vol. 349, no. 1-2, pp. 341-353. http://dx.doi.org/10.1007/s11104-011-0879-7.

VITOUSEK, P.M., PORDER, S., HOULTON, B.Z. and CHADWICK, O.A., 2010. Terrestrial phosphorus limitation: mechanisms, implications, and nitrogen-phosphorus interactions. Ecological Applications, vol. 20, no. 1, pp. 5-15. http://dx.doi.org/10.1890/080127.1. PMid:20349827.

WALLIS, M. and BOBBINK, R., 2017. Nitrogen deposition impacts on biodiversity in terrestrial ecosystems: mechanisms and perspectives for restoration. Biological Conservation, vol. 212. http://dx.doi.org/10.1016/j.biocon.2017.01.017.

ZHANG, H., LI, W., ADAMS, H.D., WANG, A., WU, J., JIN, C., GUAN, D. and YUAN, F., 2018. Responses of woody plant functional traits to nitrogen addition: A meta-analysis of leaf economics, gas exchange, and hydraulic traits. Frontiers of Plant Science, vol. 9, pp. 683. http://dx.doi.org/10.3389/fpls.2018.00683. PMid:29875787. 